\title{
JUURNAL.RU
}

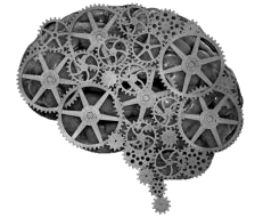

COMPANY GROUP "INTELLEKT"

\author{
Басий Р.В., Довгялло Ю.В., Костин Р.А. \\ Донеикий национальный медицинский университет им. М. Горького \\ Донеик, Украина
}

doi: 10.18411/lj2016-9-1-02

idsp 000001: lj2016-18-1-02

\section{Анатомическая индивидуальная изменчивость пазухи клиновидной кости}

Пазуха клиновидной кости находится под пристальным вниманием врачей разных специальностей. Ее удаленное расположение в системе костей черепа вызывает определенные сложности при попытке прижизненного исследования. Особенно возрастает потребность в знании строения пазухи клиновидной кости при оперативных пособиях на основании мозга и образованиях турецкого седла. Грозным осложнением подобных вмешательств может быть повреждение близлежащих структур, кровотечение и ликворея. Одним из методов предупреждения внутри- и послеоперационных осложнений является знание вариантов анатомического строения пазухи клиновидной кости, таких как: количество полостей, количество перегородок, наличие дополнительных костных образований (пластинок), форма. Особенность расположения пазухи клиновидной кости в системе черепа вносит свои коррективы в прижизненные методы исследования.

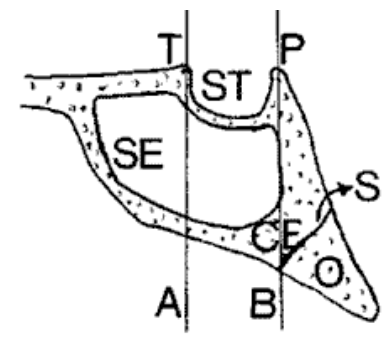

Рис. 1 Степени пневматизации клиновидной пазухи по Paulo Cesar J. Dias1et al., 2004

A - линия проходящая через переднюю стенку турецкого седла; В - линия проходящая через спинку турецкого седла; O - затылочная кость; ST - турецкое седло; T - бугорок турецкого седла; SE - пазуха клиновидной кости; СЕ - тело клиновидной кости; Р - спинка турецкого седла; S - скат. 
Учитывая вышесказанное, более рациональным для прижизненной визуализации клиновидной пазухи является использование высокоинформативных методов с возможностью анализа полученных результатов, к таким методам можно отнести и компьютерную томографию [1]. Использование компьютерной томографии в предоперационной подготовке с оценкой вариантной анатомии строения пазухи клиновидной кости поможет в планировании оперативного пособия и снизит риск как внутри-, так и послеоперационных осложнений.

Цель исследования: определить виды анатомического строения пазухи клиновидной кости.

Материалы и методы: исследованы 204 компьютерные томограммы черепов условно здоровых людей, выполненные на аппарате Philips (срезы производились с шагом 0,3 мм в двух проекциях - сагиттальной и горизонтальной) в условиях диагностических центров г. Донецка и области. Все исследованные черепа были ранжированы по полу, возрасту, форме черепа (соотношение длинны черепа к его ширине (g-op)/(eu-eu)*100). Изучена степень пневматизации пазухи клиновидной кости (рис. 1) [2,3], форма пазуха в аксиальной проекции (рис. 2), количество перегородок и полостей, дополнительные костные образования внутри пазухи.
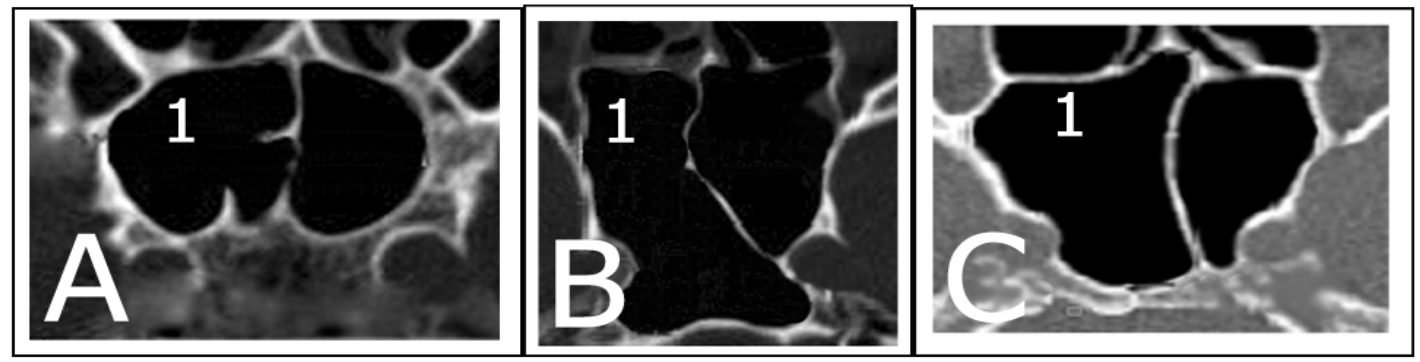

Рис. 2 Формы пазухи клиновидной кости на аксиальных срезах по данным компьютерной томографии А - овальная; В - цилиндрическая; С - конусовидная; 1 - пазуха клиновидной кости.

Результаты. По степени пневматизации можно выделить три анатомических варианта строения пазухи клиновидной кости: преселлярный, селлярный, постселлярный. Самым часто встречающимся вариантом оказался селлярный тип пневматизации - 104 томограммы черепа имели подобный тип пневматизации пазухи клиновидной кости, что составило 47,7\%, всех исследованных томограмм. Томограмм с постселлярным типом пневматизации 
выявлено 86, что составило 39,4\%, томограмм с преселлярным типом выявлено 28 , что составило 12,8 \% всех исследованных изображений.

Внутри полости пазухи клиновидной кости чаще всего присутствует одна перегородка разделяющая полость пазухи на две камеры. Таких случаев в данном исследовании выявлено 57,3\%. Более двух полостей, формирующих клиновидную пазуху, обнаружены на 12 исследованных томограммах, что составило 5,5\%. При этом, случаев деления пазухи клиновидной кости на три полости обнаружено 2,3\% (5 томограмм); случаев деления пазухи клиновидной кости на четыре полости обнаружено 3,2\% (7 томограмм). Одна полость пазухи клиновидной кости обнаружена лишь на двух томограммах (0,9\%);.

Как вариант анатомического строения пазухи может рассматриваться наличие дополнительных перегородок и костных образований стенок, образующих в полости дополнительные карманы и углубления. Чаще всего, это одна или две дополнительные структуры, что составляет $40,4 \%$ и реже три и более дополнительных образования, что составляет $3,3 \%$ от общего числа исследованных изображений пазухи клиновидной кости.

На аксиальных срезах при компьютерной томографии можно выделить три формы пазухи клиновидной кости (рис. 2): овальную, цилиндрическую, конусовидную. В данном исследовании самой часто встречающейся оказалась овальная форма (87 случаев), конусовидная форма выявлена в 86 случаях, а цилиндрическая форма выявлена всего в 45 случаях, что составило 20,6\%.

Выводы. При планировании оперативных пособий на основании мозга и турецком седле важно использовать компьютерную томографию, что дает возможность прижизненно оценить строение пазухи клиновидной кости и выявить варианты ее анатомического строения, которые могут повлиять на ход операции, а также, уменьшить риск интра- и послеоперационных осложнений. 


\section{Литература:}

1. Храппо Н.С., Тарасова Н.В. - Нос в системе целого черепа. - Самара, СамГМУ, 1999. - 172c.

2. Paulo Cesar J. Dias, Pedro Luiz M. Albernaz, Hélio K. Yamashida - Anatomical relationship between the optic nerve and the sphenoid sinus: a computed tomography study.- Artigo Original. - 2004 Vol. 70 Ed. 5 - (11), pp. 651 to 657.

3. Akaber M. Halawi, Patrick E. Simon, Alcina K. Lidder - The Relationship of the Natural Sphenoid Ostium to the Skull Base - Laryngoscope, 2015,125:7579 